\title{
全電化戸建住宅における世帯特性に応じた省エネルギー行動の提案に関する研究 実施容易性とエネルギー削減効果により推奨される行動 \\ STUDY ON SUGGESTIONS OF ENERGY-SAVING BEHAVIORS SUITABLE FOR DIFFERENT HOUSEHOLD CHARACTERISTICS IN ALL-ELECTRIC DETACHED HOUSING
}

Recommended behavior in terms of ease of implementation and energy reduction effect

\author{
遠藤裕 太*, 須永修通**, 小野寺 宏子***, 川上祐司*, 畑 泰彦**** \\ Yuta ENDOH, Nobuyuki SUNAGA, Hiroko ONODERA, \\ Yuji KAWAKAMI and Yasuhiko HATA
}

\begin{abstract}
Energy-saving behaviors of single-family-house residents in various areas in Japan were studied. The ease and energy-reduction effect of their energy-saving behaviors were investigated to determine suitable energy-saving behaviors for different household characteristics. The following conclusions were obtained; 1) the energy reduction effect and ease of 52 energy-saving behaviors for different household characteristics are presented. Recommended energy-saving behaviors suitable for each household characteristics type are then listed based on the study results. 2) Compared to the families who do not take energy-saving behaviors, those who usually take energy-saving behaviors tend not to feel that such behaviors are a bother.
\end{abstract}

\section{Keywords : Energy-saving behavior, HEMS, Single-family-house, Household characteristic, Questionnaire survey, Electricity consumption for specific use 省エネ行動，HEMS，戸建住宅，世帯特性，アンケート調査，用途別消費電力量}

\section{1. はじめに}

近年，地球温暖化等の環境問題を背景に，エネルギー消費の大幅 な削減が求められている。しかし家庭部門ではライフスタイルの変 化等の影響を受け, 2012年度の最終エネルギー消費量は1990年度比 で約 $23.2 \%$ 増加1)しており，住宅分野における省エネ対策が早急に 求められている。住宅における省エネ対策のうち, 断熱や自然エネ ルギー利用等のハード面ではその効果が明らかにされ, 対策が進め られている。しかし，居住者の住まい方等のソフト面については, 効果や実施容易性等が明確ではないことから,あまり進んでいない。 2011年の東日本大震災を機に, 省エネ行動の実施率が増加し2), その結果, 2012 年度の家庭部門のエネルギー消費量は2010年度比で $5.0 \%$ 減少した 1 )。しかし震災から 3 年が経過し, 居住者の省エネに 対する意識が低下 ${ }^{3}$ している傾向が見られ, 省エネ行動の継続が課 題となっている。省エネ行動は, 家族構成や省エネ意識等の世帯特 性により取り組みや寸さが異なると考えられる。例えば, 高齢者や 子どもと同居している世帯や夫婦だけで暮らしている世帯では, 実 施できる省エネ行動に違いが生じると予想される。また省エネ行動 個々の省エネ効果についても明確になっていない。従って, 省エネ 行動を普及させるためには, 省エネ行動の実施しやすさや効果を明
らかにするとともに，家族構成等の世帯特性ごとに適切な省エネ行 動を提案する必要があると考えられる。 省エネ行動に関する研究は，種々行われてきた4) 18)。例えば，主 にエネルギー削減効果に関するものとして, 村上ら ${ }^{4)}$ は省エネ行動 の実施世帯率増加による2050年までの $\mathrm{CO}_{2}$ 削減効果を示し, 省エネ 行動の有効性を明示した。また井上ら 5, 6, 7) 訬省エネ行動の実行率や 世帯収入等の世帯特性が住宅の年間総エネルギー消費に与える影響 について明らかにした。しかし，これらは省エネ行動個別のエネル ギー削減効果については検討していない。小峯ら ${ }^{8), 91}$ は, 個別電力七 ンサーから評価した省エネ効果と実施度合いから省エネ行動の定量 的な効果と難易度を把握したが，推奨される省エネ行動の提案まで は行っていない。

省エネ行動の提案に関する研究としては，井上ら 10$)$ は浴室におけ る快適性と省エネ性を両立した入浴スタイルを提示した。また石田 ら 11),12)はHEMS（Home Energy Management System）を用いた住 宅の空調，照明設備のエネルギー制御に関する研究を行い，省エネ 行動促進によるエネルギー削減の可能性を示唆した。伊香賀ら 13 のの 研究では, 住宅のエネルギー使用実績とライフスタイルから各世帯 に効果的な省エネ行動提案ツールを構築し, 上野ら $\left.{ }^{14}\right)$ は, 居住者個

\footnotetext{
本論文は，既発表報告 22）,23，24）,25）,26，27）,28，29，30),31）に新しい検討を加え，加筆，再構築したものである。 首都大学東京都市環境科学研究科建築学域 Grad. Stud., Dept. of Arch. and Bld. Eng., Tokyo Metropolitan Univ. 大学院生·工修

** 首都大学東京都市環境科学研究科建築学域 教授・工博

*** 首都大学東京都市環境科学研究科建築学域 補助研究員

**** 積水化学工業(侏)

Prof,, Tokyo Metropolitan Univ., Dr.Eng.

Assistant, Dept. of Arch. and Bld. Eng., Tokyo Metropolitan Univ.

Sekisui Chemical Co., Ltd.
} 
Table 3 Energy-saving behavior list (52 items)

\begin{tabular}{|c|c|c|c|c|}
\hline \multirow{11}{*}{ 空 } & 分類 & 番号 & & 省エネ行動項目 \\
\hline & \multirow{3}{*}{ 冷房 } & 1 & \multicolumn{2}{|c|}{ 設定温度を上げる } \\
\hline & & 2 & \multicolumn{2}{|c|}{ 使用時間を短くする } \\
\hline & & 3 & \multicolumn{2}{|c|}{ 使用しない } \\
\hline & \multirow{3}{*}{ 暖房 } & 4 & \multicolumn{2}{|c|}{ 設定温度を下げる } \\
\hline & & 5 & \multicolumn{2}{|c|}{ 使用時間を短くする } \\
\hline & & 6 & \multicolumn{2}{|c|}{ 使用しない } \\
\hline & フィルタ & 7 & \multicolumn{2}{|c|}{ 空調機器のフィルタを掃除する } \\
\hline & \multirow{3}{*}{ 室外機 } & 8 & \multicolumn{2}{|c|}{ 天板の上から水をかける } \\
\hline & & 9 & \multicolumn{2}{|c|}{ 周りを掃除する } \\
\hline & & 10 & \multicolumn{2}{|c|}{ 日除けをする } \\
\hline \multirow{8}{*}{$\begin{array}{l}\text { 給 } \\
\text { 湯 }\end{array}$} & \multirow{8}{*}{ 給湯 } & 11 & 夏季 & \multirow{3}{*}{ 給湯温度を下げる } \\
\hline & & 12 & 中間期 & \\
\hline & & 13 & 冬季 & \\
\hline & & 14 & 夏季 & \multirow{3}{*}{ 湯はり温度を下げる } \\
\hline & & 15 & 中間期 & \\
\hline & & 16 & 冬季 & \\
\hline & & 17 & 夏季 & \multirow{2}{*}{ シャワーのみで済ます } \\
\hline & & 18 & 冬季 & \\
\hline
\end{tabular}

\begin{tabular}{|c|c|c|c|}
\hline \multirow{6}{*}{$\begin{array}{l}\text { 家 } \\
\text { 電 } \\
\text { 機 } \\
\text { 器 }\end{array}$} & 分類 & 番号 & 省エネ行動項目 \\
\hline & \multirow{5}{*}{$\begin{array}{c}\text { 食器洗い } \\
\text { 乾燥機 }\end{array}$} & 37 & 給湯温度を高く設定する \\
\hline & & 38 & 乾燥機能を使用しない \\
\hline & & 39 & 高速モードを使用する \\
\hline & & 40 & 使用回数を減らす \\
\hline & & 41 & 使用しない \\
\hline \multirow{11}{*}{$\begin{array}{l}\text { そ } \\
\text { の } \\
\text { 他 }\end{array}$} & \multirow{2}{*}{ 照明 } & 42 & こまめに消す \\
\hline & & 43 & 家族が集って過ごす \\
\hline & \multirow{3}{*}{$\begin{array}{c}\text { 温水洗浄 } \\
\text { 便座 }\end{array}$} & 44 & 設定温度を下げる \\
\hline & & 45 & 省エネモードにする \\
\hline & & 46 & 便座のスイッチを切る \\
\hline & 通風 & 47 & 天公・窓開けで通風を図る \\
\hline & 打ち水 & 48 & 打ち水をする \\
\hline & \multirow{4}{*}{ 待機電力 } & 49 & コンセントを抜く \\
\hline & & 50 & テーブルタップの電源を切る \\
\hline & & 51 & 主電源を切る \\
\hline & & 52 & 機器設定をエコモードにする \\
\hline
\end{tabular}

人の選好や省エネ効果等を基に居住者個人に適応した省エネ行動を 分析している。また岡本ら $\left.{ }^{15)}, 16\right)$ は, 居住者一人ひとりの性格や嗜好 を反映させた個別提案手法について提示している。しかしながら, これらの研究は, 省エネ行動を実施していない, もしくは, 調查前 から実施している世帯を対象にアンケートを行っており, 省エネ行 動を初めて実施した世帯の心理的評価の分析, 寸なわち省エネ行動 ごとの実施容易性については明らかにしていない。

そこで本研究では, 世帯特性に応じた省エネ行動を提案すること を目標とし, 日本各地（北日本と沖縄を除く）の戸建住宅を対象と して, 省エネ行動の実施を要請し, 実施時の心理的評価等に関する アンケート調查と消費電力測定から, 省エネ行動の実施容易性とそ の効果を分析した。またそれらの結果から, 世帯特性ごとの推奨省 エネ行動について検討した。本報では, まず省エネ行動実施の有無 による居住者の心理的評価とエネルギー消費の違いを示す。次に, 実際に省エネ行動を行った世帯を対象に省エネ行動実施によるス卜 レスや省エネ行動の継続率, エネルギー削減量等を示し, さらにそ れらの結果から世帯特性に応じた推奨省エネ行動について検討した 結果を示す。

\section{2. 調査概要}

\section{1 対象世帯}

Table 1に対象世帯の概要, Fig.1に世帯特性の分布を示す。「省エ ネ行動実施邸 (以下, 実施邸)」は様々な省エネ行動の実施を要請 した世帯のことを示し,「省エネ行動未実施邸（以下，未実施邸）」 は省エネ行動の実施は要請せずアンケートのみに回答してもらった 世帯を示寸。対象世帯は協力を得られた注1) 北日本と沖縄を除く日本 各地の戸建住宅142世帯（「実施邸」76,「未実施邸」66）であり, 太陽光発電パネルやHEMSなどを搭載する全電化高性能戸建住宅 である。一部の対象世帯では家電製品の消費エネルギーも含めた正 味のゼロエネルギーを実現している17)。また全世帯とも工法や断熱 基準, 換気・給湯設備は同様な仕様であるが, 冷暖房設備はHP式空 調・除湿システム+個別エアコンが多く,「未実施邸」の一部に蓄熱 暖房や個別エアコンのみの世帯がある。

\section{2 アンケート調査・電力測定}

Table 2にアンケート調查・電力測定の概要を示す。アンケート調 查項目は, 日常の生活における居住者の省エネ意識や省エネ行動に 対する評価, 行動実施の内容等の把握を目的とし,「実施邸」に対し
Table 1 Summary of target residences

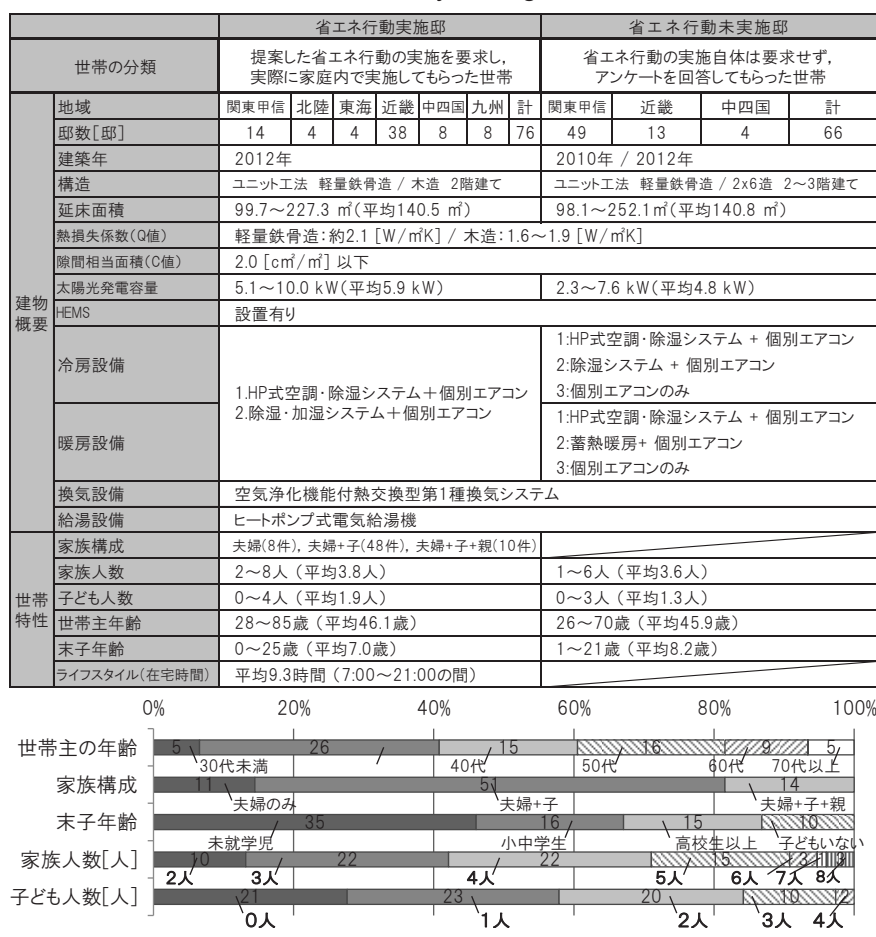

Fig.1 Household characteristics

Table 2 Summary of survey

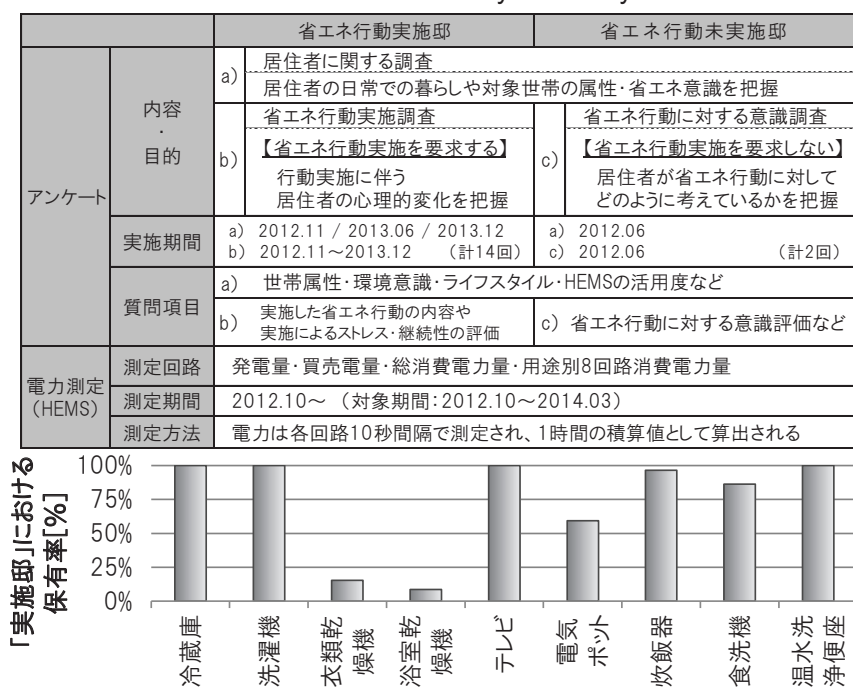

Fig.2 Average ownership ratio of home appliances 
て「居住者属性およびその意識に関する調査」および「省エネ行動 実施に関する調查」,「未実施邸」に対して「居住者属性・意識」, 両 邸に対して「省エネ行動に対する意識」等とした。Table 3に本研究 で用いた省エネ行動52項目を示寸注2)。省エネ行動の選定は文献 18), 19),20)等を参考に行った。対象世帯の家電機器の保有率をFig. 2 に示 寸注3)。また「実施邸」におけるアンケート調査の実施内容をTable 4 に示す。「居住者属性およびその意識に関する調查」は3回実施し, 「省エネ行動実施に関する調查」は, 表中の実施内容のように, 省 エネ行動の季節性に考虑して暖房編や給湯編等 23 編, 計 11 回行った 注4)。居住者は, 提示された省エネ行動の中から実施可能な省エネ行 動を選択して, できるだけ 3 日間注5)，なるべく連続して実施し，その 実施有無や実施内容, その評価を回答する。Table 5にアンケートで 用いた省エネ行動に対する各評価項目の定義と評価点を示す。また, Fig.3に各アンケートにおける回答者の割合を示寸注6)。なお，「未実 施邸」では省エネ行動実施の要請はせず，日常生活の状態で省エネ 行動に対する意識について回答してもらった。また,「未実施邸」で 調査をした省エネ行動の評価は「面倒度」のみである。

消費電力量は発電量 $\cdot$ 売買電量 - 総消費電力量 $\cdot$ 用途別 8 回路の 消費電力量をHEMSによって各々 10 秒間隔で測定し，1時間の積算 值として算出される注7)。電力量は2012年10月から測定を続けてい るが, 本研究では2012年10月から2014年3月までの電力データを対 象として解析する。また電力データの久損に関しては重回帰分析を 用いてデータの補正を行った注8)。

\section{3. 省エネ行動実施邸と未実施邸のアンケート結果の比較}

「未実施邸」ではTable 3に示寸全ての省エネ行動についてアンケ 一ト調査を行っていないため, 「実施邸」と「未実施邸」で評価の比 較が可能である 22 項目について解析した。

\section{1 面倒臭さの評価}

Fig.4に「実施邸」と「未実施邸」の省エネ行動に対する面倒臭さ の評価を示す。なお第3章での「実施邸」は日常的に省エネ行動を
Table 4 Content of implementation in questionnaire

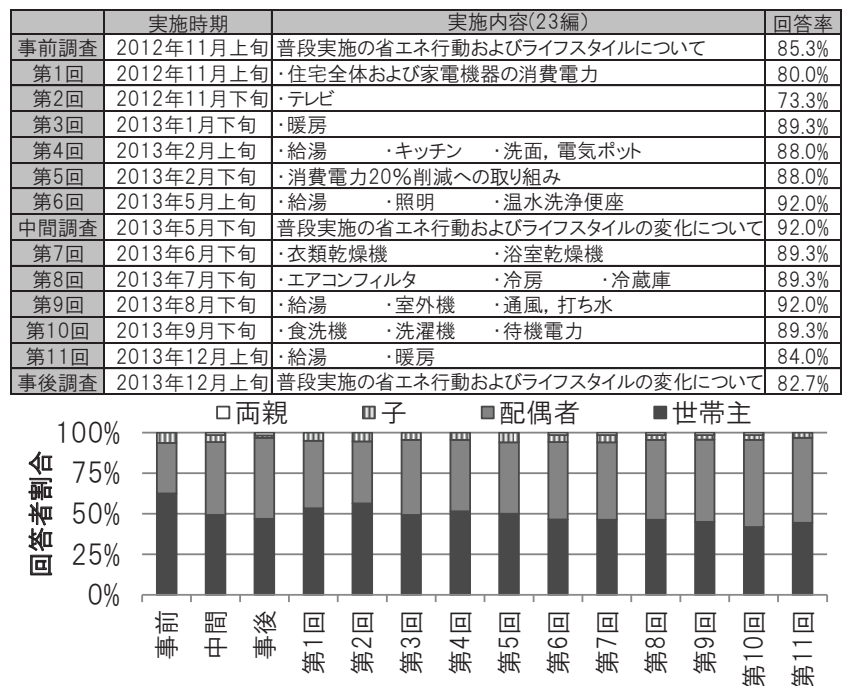

Fig.3 Classification of respondent in each questionnaire

Table 5 Evaluation of energy-saving behaviors

\begin{tabular}{|c|c|c|c|c|}
\hline & 面倒度 & ストレス & 継続性 \\
\hline \multicolumn{2}{|c|}{ 定義 } & $\begin{array}{l}\text { 省エネ行動を } \\
\text { 面倒に感じるか }\end{array}$ & $\begin{array}{l}\text { 省エネ行動を実施してスた } \\
\text { に感じス }\end{array}$ & $\begin{array}{l}\text { 省エネ行動を継続的に実 } \\
\text { 施できるか }\end{array}$ \\
\hline \multirow{4}{*}{ 点 } & 0 点 & 面倒ではない & 【A】大変ストレスを感じた & 【A】継続しないてできない \\
\hline & 1点 & 少し面倒 & 【A】の意見に近い & 【A】の意見に近い \\
\hline & 2 点 & 面倒 & 【B】の意見に近い & 【B】の意見に近い \\
\hline & 3 点 & 非常に面倒 & 【B】特にストレスを感じなかった & 【B】継続したい・できる \\
\hline
\end{tabular}

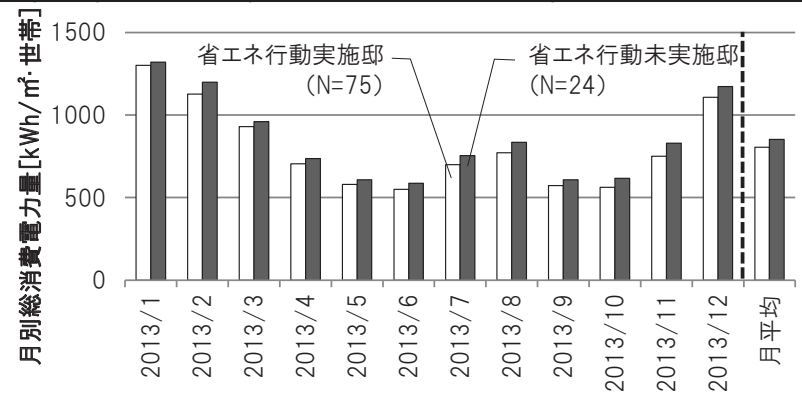

Fig.5 Average monthly-total energy consumption

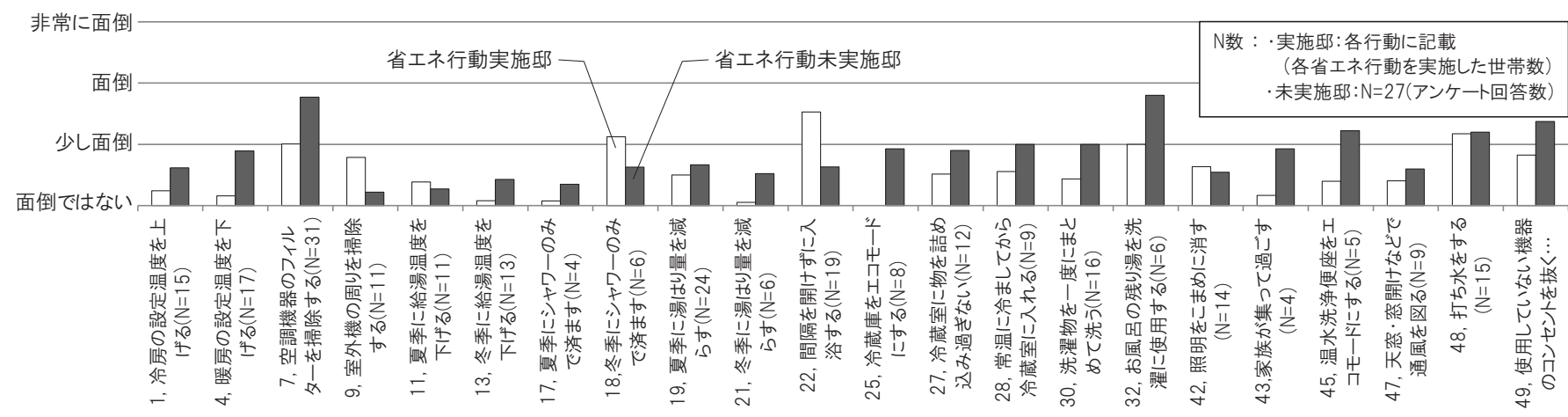

Fig.4 Evaluated inconvenience for households who take energy-saving behaviors and those who do not

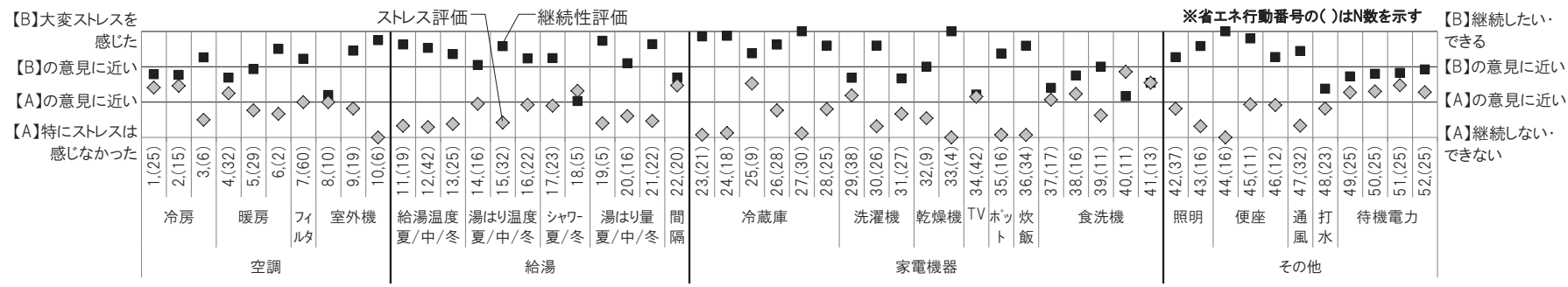

Fig.6 Evaluation of stress and persistence of energy-saving behaviors 
継続して行っていなかった世帯（アンケート到着後にその省エネ行 動を実施した世帯）であり, 省エネ行動の実施要請有無による評価 を比較する。22項目のうち 16 項目で「実施邸」の方が「未実施邸」 よりも面倒臭さの評価が低い。このことから省エネ行動を実際に行 うことで, 実施しない場合よりも居住者が感じる面倒臭さは少なく なると考えられる。ただし「9. 室外機の掃除」「18. 冬季にシャワー のみ」「22.間隔を開けずに入浴」では「実施邸」の方が「未実施邸」 よりも面倒臭く思う傾向にある。これは屋外作業をしなければなら ないことや居住者の帰宅時間が異なる等の理由で, 居住者が実施前 に考えていた以上に実施後の方が面倒臭さを感じたことが一因であ ると推察される。

3.2 エネルギー消費傾向
Fig.5に対象世帯の平均月積算エネルギー消費量を示す。対象世帯 は電力測定の有効データを取得できた「実施邸」75,「未実施邸」 24 の9世帯を対象としている。「実施邸」の月平均消費量は約 805 $\mathrm{kWh}$ であり，「未実施邸」は約 $852 \mathrm{kWh}$ である。これらを比較する と,「実施邸」の方が月平均で $47.4 \mathrm{kWh}$, 年間で約 $568 \mathrm{kWh}(5.6 \%)$ 少ない。このことから省エネ行動を居住者に提案することによるエ ネルギー消費の低減が可能であると推察される。

\section{4. 省エネ行動の実施しやすさ}

本章以降では,「実施邸」を対象に解析を行った結果を示寸。

4. 1 ストレス・継続性評価

Fig.6に各省エネ行動を居住者が実施した際に感じたストレスと

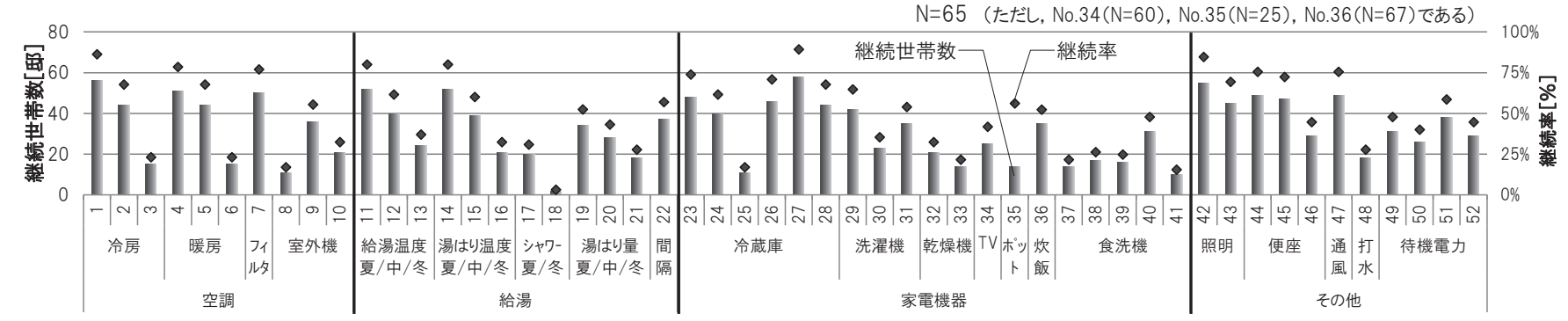

Fig.7 Number of successively-implemented energy-saving behaviors, and persistence rate

Table 6 Persistence rate for different household characteristics

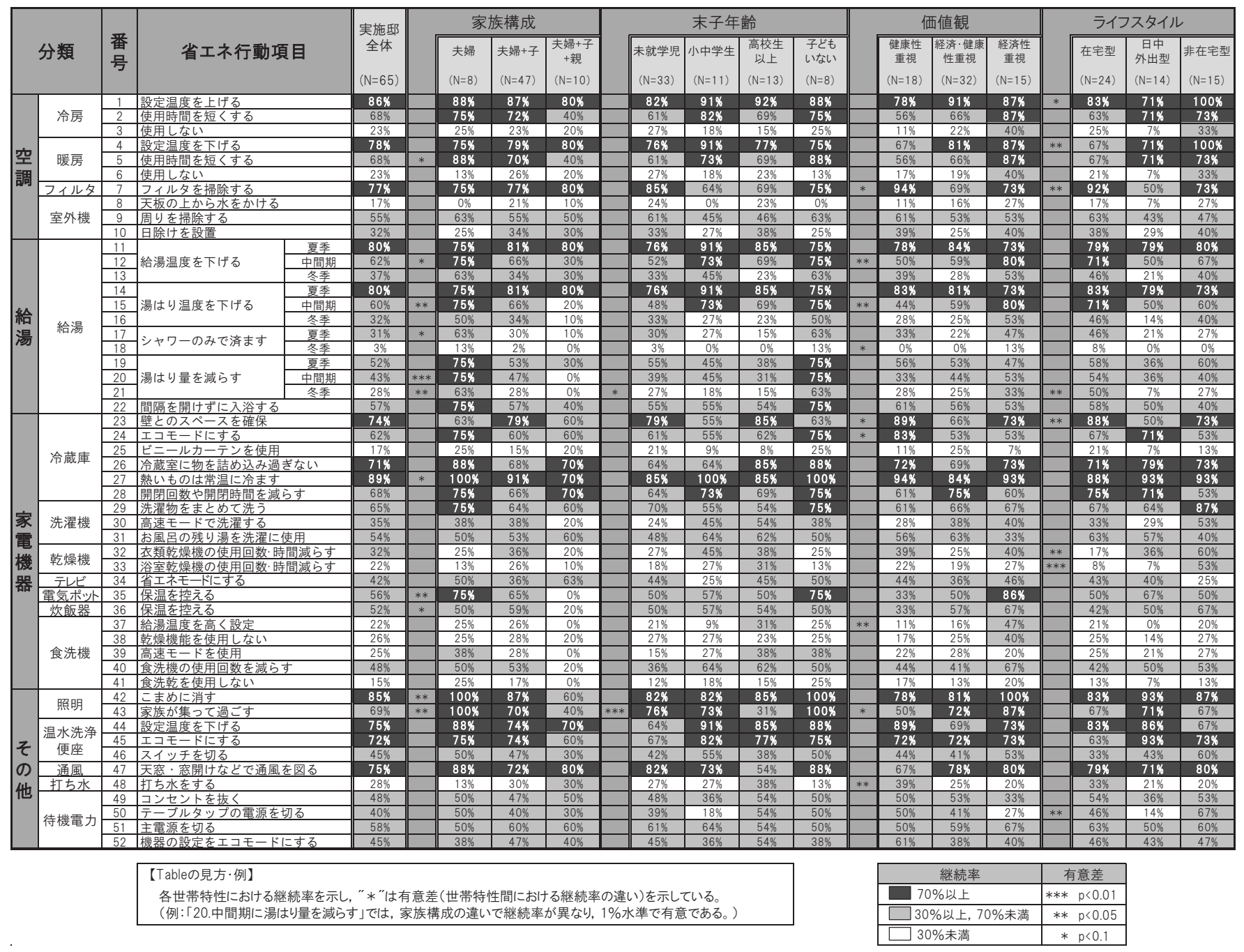


継続性の平均評価を示す。多くの省エネ行動は継続して実施でき, かつストレスは感じない傾向にある。しかし「18.冬季にシャワーの み」「8.室外機に水をかける」等では継続性が低くなる傾向にあり， 「40.食洗機の使用回数減少」ではストレスを感じる傾向にある。 給湯分野では,「18. 冬季にシャワーのみ」「22.間隔を開けずに入 浴」においてストレスを感じる傾向にある。この理由として［浴槽 に浸かって体を温めたい，［家族の帰宅時間が異なる］などの居住 者の意見が挙げられた。またテレビや待機電力に関する省エネ行動 では継続性が低い行動があり，[一日に何度も面倒だから］という意 見や，食洗機では［肌が荒れるから］等の意見もあった。

\section{2 継続率}

Fig.7に「実施邸」全体において, 省エネ行動を調查前から実施し ていた世帯と本調查後（省エネ行動実施調查後）に継続的に実施す るようになった世帯を合わせた割合（継続率）を示す注 9 )。行動全体 の平均継続率は $50.1 \%$ (32世帯) であり, 最大は「 27 . 常温に冷まし てから冷蔵室に入れる」で $89.2 \%$, 最小は「18.冬季にシャワーのみ」 の $3.1 \%$ であった。

空調分野では「3.および6.使用しない」の割合が低い傾向にあり， 使用方法を制限するよりも使用自体を制限する行動の方が継続しづ らいと考えられる。また「8. 室外機に水をかける」では一日に何度 も屋外で作業しないといけないため継続率が低いと考えられる。

給湯分野では「11〜13. 給湯温度を下げる」「14〜16.湯はり温度を 下げる」「17・18.シャワーのみ」「19２1.湯はり量を減らす」にお いて, 夏季から冬季に季節が変わるにつれて継続率が低下寸る傾向 にある。また設定温度を変更する行動の方が湯はり量を減ら寸行動 よりも継続できることがわかる。アンケートでは, [冬季ほど風呂で 体を温め,リラックスしたいという回答が多くみられた。

家電機器では冷蔵庫に関する省エネ行動の継続率が高い傾向があ る。しかし，「25.ビニールカーテンを使用」では低い值を示してお り，[カーテンがあることで取り出しにくくなった]という居住者の 意見がみられた。また乾燥機と食洗機に関する行動では継続率が低 い傾向にあり, これは［洗濯物や食器は常に綺麗に保ちたい］［手荒 れが心配である］［今までの生活スタイルを変えることができない］ 等の居住者の意見が影響していると考えられる。

その他の分野では「42.照明をこまめに消寸」の継続率が高い傾向 にあり，手軽に行えることや実施できる機会が多いこと，テレビ等 により一般世帯にも広く認知され, 継続率が高くなったことが一因 と考えられる。一方, 「48. 打ち水をする」では低い傾向を示し, 屋 外で作業をしないといけないことが低くなった一因と考えられる。

\section{3 世帯特性による継続率の違い}

Table 6に各世帯特性（家族構成，末子年齢注 10 ，価值観，ライフ スタイル）における継続率を示す。ここでの価值観とは居住者が日 常生活の中で重要視する経済性や健康性等の価值観, ライフスタイ ルは各世帯の平日の在宅時間を示す。価值観とライフスタイルの分 類に関してはクラスター分析を用いた注11), 注12)。なお, 表中の*は 各世帯特性における有意差を示す注 13 )。また表中の継続率が $70 \%$ 以 上を濃いハッチで, $30 \%$ 未満をハッチなしで示した。「1・4.冷房（暖 房）の設定温度を上げる（下げる）」等の 12 項目が $70 \%$ 以上であり， 「18.冬季にシャワーのみで済ます」等の 11 項目が $30 \%$ 未満である。 次に家族構成をみると,「15.中間期の湯はり温度」「20・21.中間期・
冬季の湯はり量」「35.電気ポットの保温オフ」「 $42 \cdot 43$. 照明に関する 行動」等で有意差（親世代のいる世帯での継続率低下） が確認でき る。給湯関連の項目は，親世代のいる世帯では高齢者の健康等に配 慮していることが一因と考えられる。また電気ポットでは高齢者の お茶を飲む頻度が多いこと, 照明関連では二世帯住宅であるため, 家族が全員集まる機会が少ない等の原因が挙げられる。

末子年齢では「43.家族が集まって過ごす」等で有意差があり，高 校生以上の子どもがいる世帯では，子どもの意見として，[少し無理 して（家族と集まるよう）合わせたが，やはり厳しい等が挙げられ た。帰宅時間の違いや生活スタイルによる影響等により継続するこ とが困難になったと推察される。また価値観では「12.中間期の給湯 温度」「15. 中間期の湯はり温度」「48. 打ち水をする」等で有意差を 確認でき, 経済性重視の世帯において継続率が高い傾向にある。こ の理由として, 経済性を優先的に考える世帯ではエネルギー削減の ために積極的に省エネ行動を実施できるからと考えられる。

ライフスタイルでは「4.暖房の設定温度」「7.空調のフィルタ掃除」 「21. 冬季の湯はり量」「23.冷蔵庫と壁の間隔をあける」「32・33.衣 類・浴室乾燥機の使用を控える」「50.テーブルタップの電源を切る」 等で有意差が確認できる。暖房や乾燥機の省エネ行動では非在宅型 の世帯の継続率が高い傾向にある。

\section{5. エネルギー削減効果}

Fig.8に省エネ行動による一日と年間の平均エネルギー削減量を 示す。削減量は，(1)電力測定の解析結果注14)，(2)アンケートによる 居住者の回答結果 (印) 注15)から原単位 $\left(\left[\mathrm{Wh} /\right.\right.$ 日 $\cdot \mathrm{m}^{2} \cdot$ 人・世帯 $]$ ) で算出した。Fig.8では, この原単位で算出した削減量を一日および 年間の平均削減量に換算した值 $([\mathrm{Wh} /$ 日・世帯],$[\mathrm{kWh} /$ 年・世帯 $])$ にして記している注16)。その際に用いた諸条件をTable 7に示す。な お年間削減量は各省エネ行動で実施できる季節を考慮して日削減量 にTable 8で示す日数をかけた值とした。また図中のN数は省エネ行 動を実施した世帯数を示す。

空調分野において, 冷暖房では空調自体の使用を控えることで電 力を大幅に削減することができ, 設定温度を変更するだけでも削減 効果があることがわかる。

給湯分野では, 全体的に日削減量が $300[\mathrm{Wh} /$ 日・世帯]以上の省エ ネ行動が比較的多い。特に夏季よりも中間期，冬季に関する省エネ 行動の削減量が多く, 中間期, 冬季の給湯分野における省エネ実施 がエネルギー消費に大きく影響することは明らかである。また「22. 間隔をあけずに入浴」では一年を通して実施できるため，年間での 削減量が他の給湯に関する省エネ行動よりも大きくなる傾向にある。 家電機器の分野では, 日削減量が空調や給湯分野に比べて低くな る傾向にある。しかし家電機器は年間を通じて省エネ行動を実施で きるため, 年間削減量では空調や給湯分野よりも削減量が大きくな る省エネ行動がみられる。特に冷蔵庫, 洗濯機, 電気ポット, 食洗 機における年間削減量が大きい傾向にあり，住宅全体のエネルギー 消費に影響力の大きい家電機器だと考えられる。

その他の分野では, 「49・50.コンセントや家電機器の電源」等の 日削減量は比較的大きくないものの, 年間では約 $90[\mathrm{kWh} /$ 年・世帯] と削減効果が高いことが示された。家電やその他の分野では, 年間 を通じて行うことで削減量が大きくなる省エネ行動があることから， 
継続して実施していくことが特に重要な分野であると考えられる。

\section{6. 推奨省エネ行動の検討}

\section{1 エネルギー削減効果と実施容易性注17)}

Table 9に各世帯特性における省エネ行動のエネルギー削減効果 と実施容易性注17)を示す。本報では各世帯特性に推奨できる省エネ 行動を検討するため，第 4 章のストレス・継続性評価，継続率と第 5 章の年間エネルギー削減効果の結果を用いて分析を行った。分析方 法として，まず年間のエネルギー削減効果はFig.8の結果を基にAA 〜 Eの6段階に分類した。またストレス・継続性評価, 継続率はアン ケートの回答数に応じて, 評価に重みを与える加重平均を行い, 実 施容易性として，1〜5の5段階で分類した注18)。Table 9の見方とし て例を挙げると, 《削減効果が「E」で実施容易性が「1」の場合で は, 削減効果が低く, 実施も推奨できないため, この省エネ行動は 推奨できない省エネ行動だと考えられる》等がある。

全世帯を通してエネルギー削減効果，実施容易性が高い省エネ行 動は，「4.暖房の設定温度を下げる」「5.暖房の使用時間短縮」「12. 中間期の給湯温度を下げる」「24.冷蔵庫をエコモードに設定」「27. 常温に冷ましてから泠蔵庫に入れる」の5項目あり, これらは実施 しやすく省エネ効果が高いことから推奨しや寸い省エネ行動と考え られる。また「3.および6.冷房・暖房を使用しない」「22.間隔あけず に入浴」「38. 食洗機の乾燥機能を使用しない」では削減効果が高い が，実施容易性の評価は低い傾向にある。そのため評価が3（どち らとも言えない）の行動，かつ居住者の環境配慮や電気代削減等へ の意識が高く, 実施の意欲がある世帯では, 省エネ行動の実施を推 奨できると考えられる。

次に世帯特性ごとにみると, 家族構成においては「16.冬季の湯は り温度」「20・21.中間期・冬季の湯はり量」等では夫婦のみの世帯で 実施容易性が高い。これは子どもや親世代がいないことで実施に対 する許容範囲が広がったためと考えられる。また「35.電気ポットの 保温オフ」では家族構成が「夫婦」,「夫婦十子ども」,「夫婦十子ど も+親」の順に実施容易性が低くなる傾向がある。これは高齢者へ のお茶等ですぐにお湯を使用する頻度が多いことややけど等の事故 への配慮が一因であると推察される。

末子年齢による分類では, 子どもがいない世帯で「17.夏季のシャ ワーのみ」「19.夏季の湯はり量」等の実施容易性が高い傾向にある。 また子どもがいない世帯では, 子どものいる世帯に比べて実施の評 価が1〜2段階高い傾向にあり, 子どもの世話がないため省エネ行動 の継続的な実施が容易になる等の理由が考えられる。

価值観による分類では，経済性を重視する世帯で「16.冬季の湯は り温度」「46.温水洗浄便座の電源を切る」が推奨しやすいという結 果が示唆される。また経済性を重視する世帯では「42・43.照明に関 する省エネ行動」等の実施容易性が他を重視する世帯よりも高い。 これは居住者の電気代削減への意欲が高いため, 実施容易性の評価 が高くなったことが一因と考えられる。

ライフスタイルによる分類では，一日非在宅の世帯で「32・33.乾 燥機の使用を控える」の実施容易性が高くなる傾向がみられる。

\section{2 推奨省エネ行動}

Table 9のエネルギー削減効果と実施容易性の結果を基に選出し た世帯特性に応じた推奨省エネ行動をTable 10に示す。この選出は
Table 7 Conversion condition of energy reduction amount

\begin{tabular}{|l|c|c|}
\hline 延床面積 & 140.5 & {$\left[\mathrm{~m}^{2}\right]$} \\
\hline 家族人数 & 3.8 & {$[\mathrm{\Lambda}]$} \\
\hline 一日当たりの空調使用時間 & 9 & {$[\mathrm{~h}]$} \\
\hline 省エネ行動で空調の使用を控えた時間数 & 3 & {$[\mathrm{~h}]$} \\
\hline 省エネ行動で変更した設定温度の度合い(空調分野) & 1 & {$\left[{ }^{\circ} \mathrm{C}\right]$} \\
\hline 省エネ行動で変更した設定温度の度合い(給湯,乾燥機分野) & 1 & {$\left[{ }^{\circ} \mathrm{C}\right]$} \\
\hline
\end{tabular}

Table 8 Period and number of days of energy-saving behaviors

\begin{tabular}{|c|c|c|}
\hline 省エネ行動 & 季節 & 日数 \\
\hline No.22 46, 49 52 & 通年 & 365 \\
\hline No.1 3, 8 11, 14, 17, 19, 48 & 夏季(6〜9月) & 122 \\
\hline No. $12,15,20$ & 中間期 (4,5,10,11月) & 122 \\
\hline No.4 6, 13, 16, 18, 21 & 冬季(12３月） & 121 \\
\hline No.47 & 夏季.中間期(4～11月) & 244 \\
\hline No.7 & 夏季.冬季 (6〜9,12３月) & 243 \\
\hline
\end{tabular}

日削減量[Wh/日·世帯]

$0300 \quad 600 \quad 900 \quad 1200$

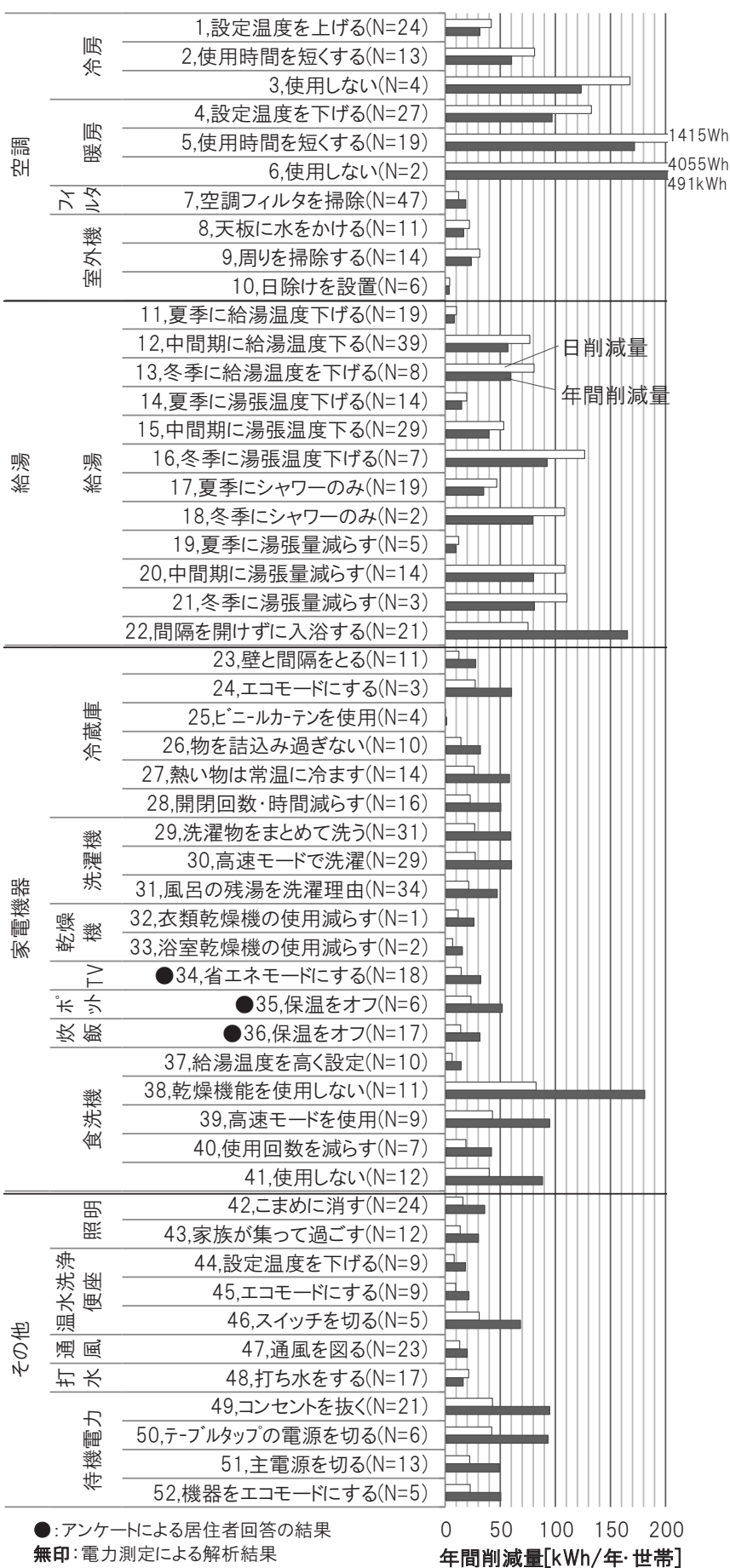

Fig.8 Average energy reduction by energy-saving behaviors 
Table 9 Energy reduction effect and ease of implementation of energy-saving behaviors for different household characteristics

\begin{tabular}{|c|c|c|c|c|c|c|c|c|c|c|c|c|c|c|c|c|c|c|}
\hline \multirow{4}{*}{\multicolumn{2}{|c|}{ 分類 }} & \multirow{4}{*}{$\begin{array}{l}\text { 番 } \\
\text { 号 }\end{array}$} & \multirow{4}{*}{\multicolumn{2}{|c|}{ 省エネ行動項目 }} & \multirow{4}{*}{$\begin{array}{c}\text { エネル } \\
\text { ギ一削減 } \\
\text { 効果 }\end{array}$} & \multicolumn{13}{|c|}{ 省エネ行動の实施容易性 } \\
\hline & & & & & & \multicolumn{3}{|c|}{ 家族構成 } & \multicolumn{4}{|c|}{ 末子年齢 } & \multicolumn{3}{|c|}{ 価値観 } & \multicolumn{3}{|c|}{ ライフスタイル } \\
\hline & & & & & & 夫婦 & 夫婦+子 & $\begin{array}{c}\text { 夫婦+子+ } \\
\text { 親 }\end{array}$ & 未就学児 & 小中学生 & $\begin{array}{c}\text { 高校生以 } \\
上\end{array}$ & $\begin{array}{l}\text { 子どもいな } \\
\text { い }\end{array}$ & $\begin{array}{l}\text { 健㡺性 } \\
\text { 䄈 }\end{array}$ & 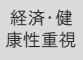 & $\begin{array}{l}\text { 経済性 } \\
\text { 重視 }\end{array}$ & & \begin{tabular}{|c|} 
日中外出 \\
型
\end{tabular} & 非在宅型 \\
\hline & & & & & & & & & & & & & & $(\mathrm{N}=32)$ & & & & $(N=15)$ \\
\hline & \multirow{3}{*}{ 冷房 } & 1 & \multirow{2}{*}{\multicolumn{2}{|c|}{ 設定淐度を上けザる }} & $\mathrm{c}$ & 4 & 4 & 4 & 4 & 4 & 4 & 4 & 4 & 4 & 4 & 4 & 4 & 4 \\
\hline \multirow{9}{*}{ 空 } & & 2 & & & B & 4 & 4 & 3 & 3 & 4 & 4 & 4 & 3 & 4 & 4 & & 4 & 4 \\
\hline & & 3 & & & A※ & 3 & 2 & 3 & 2 & 2 & 2 & 3 & 2 & 2 & 3 & 2 & 2 & 3 \\
\hline & & 4 & 設定温度を下げる & & B & 4 & 4 & 4 & 4 & 4 & 4 & 4 & 4 & 4 & 4 & 4 & 4 & 4 \\
\hline & 暖房 & 5 & 使用時間を短くする & & AA & 4 & 4 & 4 & 4 & 4 & 4 & 4 & 4 & 4 & 4 & 4 & 4 & 4 \\
\hline & & 6 & 使用しない & & AA※ & 2 & 2 & 2 & 2 & 2 & 2 & 2 & 2 & 2 & 3 & & 1 & 2 \\
\hline & フィルタ & 7 & フィルタを掃除する & & D & 4 & 4 & 4 & 4 & 4 & 4 & 4 & 4 & 4 & 4 & 4 & 4 & 4 \\
\hline & & 8 & 天板の上から水をかける & & D & 2 & 2 & 2 & 2 & 2 & 2 & 2 & 2 & 2 & 2 & 2 & 2 & 2 \\
\hline & 室外機 & 9 & 周りを淿除する & & D & 4 & 4 & 4 & 4 & 4 & 4 & 4 & 4 & 4 & 4 & 4 & 4 & 4 \\
\hline & & 10 & 日除けを設置 & & E* & & & & & & 3 & & & & 3 & & & \\
\hline & & 11 & & 夏季 & $E$ & 5 & 5 & 5 & 5 & 5 & 5 & 5 & 5 & 5 & 5 & 5 & 5 & 5 \\
\hline & & 12 & 給湯温度を下げる & $\begin{array}{c}\text { 中間期 } \\
\end{array}$ & $B$ & 5 & 4 & 4 & 4 & 5 & 5 & 5 & 4 & 4 & 5 & 5 & 4 & 5 \\
\hline & & 13 & & 冬季 & $B \approx$ & 4 & 3 & 4 & 3 & 4 & 4 & 4 & 4 & 3 & 4 & 4 & 4 & 4 \\
\hline & & 14 & & 夏季 & D & 4 & 4 & 4 & 4 & 4 & 4 & 4 & 4 & 4 & 4 & 4 & 4 & 4 \\
\hline & & 15 & 湯はり温度を下げる & 中間期 & c & 5 & 4 & 4 & 4 & 5 & 5 & 5 & 4 & 4 & 5 & 4 & 4 & 4 \\
\hline 給 & & 16 & & 冬季 & $B \approx$ & 4 & 3 & 3 & 3 & 3 & 3 & 4 & 3 & 3 & 4 & 3 & 3 & 3 \\
\hline 湯 & 給湯 & 17 & & 夏季 & $\mathrm{c}$ & 4 & 3 & 3 & 3 & 3 & 3 & 4 & 3 & 3 & 4 & 3 & 3 & 3 \\
\hline & & 18 & シャヤワのみみで济ます & 冬季 & $\mathrm{B} *$ & 2 & 1 & 1 & 1 & 1 & 1 & $\frac{1}{2}$ & 1 & 1 & 2 & 1 & 1 & 1 \\
\hline & & 19 & & 夏季 & E※ & 5 & & 3 & 3 & 3 & 3 & 5 & 4 & 3 & 3 & 4 & & 4 \\
\hline & & 20 & 湯はり量を減らす & 中間期 & B & 4 & 3 & 3 & 3 & 4 & 3 & 4 & 3 & 3 & 4 & 4 & & 3 \\
\hline & & 21 & & 冬季 & $B \nVdash$ & 4 & 3 & 3 & 3 & 4 & 3 & 4 & 3 & 3 & 4 & 4 & 3 & 4 \\
\hline & & 22 & 間隔を開けずに入浴する & & AA & & 3 & 3 & 3 & 3 & 3 & & 3 & 3 & 3 & 3 & 3 & \\
\hline & & & 壁とのスペースを確保 & & $\mathrm{c}$ & 5 & 5 & 5 & 5 & 5 & 5 & 5 & 5 & 4 & 5 & 5 & 4 & 5 \\
\hline & & & エコモードにする & & $B \%$ & 5 & 4 & 5 & 4 & 5 & 5 & 5 & 5 & 4 & 4 & 4 & 5 & 4 \\
\hline & & 25 & ビニールカーテンを使用 & & E※ & & 2 & 3 & 2 & 2 & 2 & & 2 & 2 & 2 & 2 & & 2 \\
\hline & 冷蔵庫 & & 冷蔵室に物を詰め込み過 & をない & $c$ & 5 & 4 & 4 & 4 & 4 & 5 & 5 & 4 & 4 & 4 & 4 & 5 & 4 \\
\hline & & & 熱いものは常温に冷ます & & $\mathrm{B}$ & 5 & 5 & 5 & 5 & 5 & 5 & 5 & 5 & 5 & 5 & 5 & 5 & 5 \\
\hline & & 28 & 開閉回数也開閉時間を減 & & $\mathrm{c}$ & 4 & 4 & 4 & 4 & 4 & 4 & 4 & 4 & 4 & 4 & 4 & 4 & 4 \\
\hline & & 29 & 洗濯物をまとめて洗う & & $B$ & 4 & 4 & 3 & 4 & 3 & 3 & 4 & & 4 & 4 & 4 & 3 & 4 \\
\hline 家 & 洗濯機 & & 高速モードで洗濯する & & B & 4 & 3 & 4 & 3 & 4 & 4 & 4 & 4 & 4 & 4 & 4 & 4 & 4 \\
\hline 雷 & & & お風呂の残り湯を洗濯に & & $\mathrm{c}$ & 4 & 3 & 4 & 3 & 4 & 4 & 4 & 4 & 4 & 3 & 4 & 4 & \\
\hline & & 32 & 衣類乾燥機の使用回数·時 & 筒減らす & $c \%$ & 3 & 3 & 3 & 2 & 3 & 3 & 3 & 3 & 2 & 3 & 2 & 3 & 4 \\
\hline 機 & 乾燥機 & 33 & 浴窒乾燥機の使用回数·時 & 間減らす & $\mathrm{D} \%$ & 3 & 2 & 2 & 2 & 3 & 3 & 3 & 2 & 2 & 3 & 2 & 2 & 4 \\
\hline 器 & テレビ & 34 & 省エネモードにする & & $\mathrm{c}$ & 3 & 3 & 3 & 3 & 3 & 3 & 3 & & 3 & 3 & 3 & 3 & 3 \\
\hline & 電気术以下 & 35 & 保温を控える & & $B \%$ & 5 & 4 & 3 & 4 & 4 & 4 & 5 & 3 & 4 & 5 & 4 & 4 & 4 \\
\hline & 炊飯器 & & 保温を挤える & & $\frac{a n}{c}$ & 5 & $\frac{1}{4}$ & 4 & $\frac{1}{4}$ & 5 & 5 & 5 & $\frac{4}{4}$ & 4 & 5 & $\frac{1}{4}$ & 4 & 5 \\
\hline & & & 給湯温度を高く設定 & & D & 3 & 2 & 2 & 2 & & & & & & 3 & 2 & & 2 \\
\hline & & 38 & 乾燥機能を使用しない & & AA & 3 & 2 & 3 & 2 & 3 & 3 & 3 & 2 & 2 & 3 & 2 & 2 & 3 \\
\hline & 食洗機 & 39 & 高速モードを使用 & & B & 3 & 2 & 2 & 2 & 3 & 3 & 3 & 3 & 2 & 3 & 3 & 3 & 3 \\
\hline & & & 食洗機の使用回数を減ら & & $\mathrm{c} *$ & 3 & 3 & 2 & 2 & 3 & 3 & 3 & 3 & 3 & 3 & 3 & 3 & 3 \\
\hline & & 41 & 食洗乾を使用しない & & $B$ & 3 & 2 & 2 & 2 & 2 & 2 & 3 & 2 & 2 & 2 & 2 & & 2 \\
\hline & & 42 & こまめに消す & & $\mathrm{c}$ & 4 & 5 & 4 & 4 & 4 & 4 & 4 & 4 & 4 & 5 & 4 & 4 & 4 \\
\hline & 照明 & 43 & 家㵀が集って過ごす & & $\mathrm{c}$ & 5 & 4 & 4 & 4 & 5 & 4 & 5 & 4 & 4 & 5 & 4 & 5 & 4 \\
\hline & & & 設定温度を下げる & & D & 5 & 5 & 5 & $\frac{4}{4}$ & 5 & $\frac{4}{5}$ & 5 & 5 & $\frac{4}{4}$ & 5 & 5 & 5 & 5 \\
\hline & 温水洗㴋 & 45 & エコモードにする & & D & 4 & 4 & 4 & 4 & 5 & 4 & 4 & 4 & 4 & 4 & 4 & 5 & 4 \\
\hline そ & 便坐 & 46 & スイッチを切る & & $\mathrm{B} \%$ & 4 & 3 & 3 & $\frac{7}{3}$ & 4 & 3 & 4 & 3 & $\frac{4}{3}$ & $\frac{4}{4}$ & $\frac{4}{3}$ & 3 & $\frac{4}{4}$ \\
\hline の & 通風 & 47 & 天空・窓開けなどで通風 & 図る & D & 5 & 4 & 5 & 5 & 5 & 4 & 5 & 4 & 5 & 5 & 5 & 5 & 5 \\
\hline 他 & 打ち水 & 48 & 打ち水をする & & D & 3 & 2 & 3 & 3 & 3 & 3 & 3 & 3 & 2 & 3 & 3 & 3 & 3 \\
\hline & & 49 & コンセントを抜く & & B & 3 & 3 & 3 & 3 & 3 & 3 & 3 & 3 & 3 & 3 & 3 & 3 & 3 \\
\hline & & 50 & テーブルタップの電源を & & $\mathrm{B} \%$ & 3 & 3 & 3 & 3 & 3 & 3 & 3 & 3 & 3 & 3 & 3 & 3 & 4 \\
\hline & 待機電力 & 51 & 主電源を切る & & $\mathrm{c}$ & 3 & 3 & 3 & 3 & 3 & 3 & 3 & 3 & 3 & 3 & 3 & 3 & 3 \\
\hline & & 52 & 機器の設定をエコモード & 二する & $c *$ & 3 & 3 & 3 & 3 & 3 & 3 & 3 & 4 & 3 & 3 & 3 & 3 & 3 \\
\hline
\end{tabular}

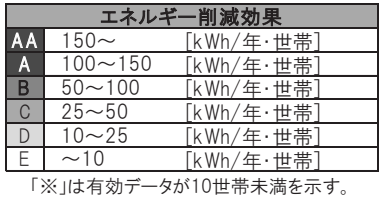

エネルギー削減効果がTable 9の「D」以上，実施容易性が「3」以 上の省エネ行動について行い, Table 10の凡例に示す5区分とした。

選出条件として, エネルギー削減効果は全国の一般的な住宅の年 間総エネルギー消費量 21 の $0.1 \%$ 程度, またはそれ以上の行動を削減 効果の大きい省エネ行動とし, 実施容易性は実施しづらい側（Table 9の実施容易性が1と2のもの) を除いた省エネ行動とした。

全ての世帯で「○」または「○」のついた，すなわち省エネ効果 が高いかつ実施しやすく, 世帯特性に関係なく推奨できる省エネ行 動は，「4.暖房の設定温度」「5.暖房の使用時間短縮」「12.中間期の 給湯温度」「24.冷蔵庫をエコモードに設定」「27. 常温に冷ましてか ら泠蔵庫に入れる」であり, 暖房や中間期の給湯分野, 比較的少な い動作で行える省エネ行動となった。次に,「16.冬季の湯はり温度」 $\lceil 20 \cdot 21$. 中間期・冬季の湯はり量」等は世帯特性により推奨可能の 判断が異なることがわかる。また家族構成で夫婦のみの世帯，末子 年齢で子どものいない世帯, 価值観で経済性を重視している世帯は 推奨できる省エネ行動が多い傾向にある。これは親や子どもの健康
(加重平均值: $0.8 \sim 1.0$ )

（加重平均値: $0.8 \sim 1.0$ ) (加重平均値: $0.4 \sim 0.6$ ) (加重平均値: $0.2 \sim 0.4$ )

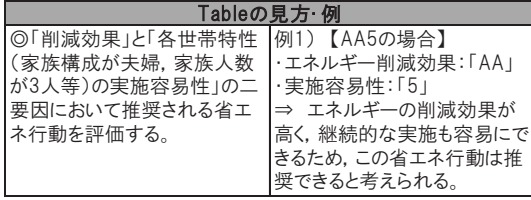

面，世話等を気にせずに実施できることや電気代削減のため，多少 の我慢を強いられても許容できるためと考えられる。

「どちらかと言えば推奨できる $(\triangle) 」 に$ に該当する省エネ行動はエ ネルギー削減効果が「C」または「D」で，実施容易性が「4」また は「5」であり，省エネ効果は比較的低いが実施しやすい省エネ行 動といえる。この省エネ行動には「 $23 \cdot 26 \cdot 28$.冷蔵庫に関する省エ ネ行動」「36.炊飯器の保温を控える」「 $42 \cdot 43$. 照明に関する省エネ行 動」「47.通風を図る」等があり, これらは世帯特性に関係なく推奨 できる可能性が示唆された。「 $\triangle 」 に$ 該当する省エネ行動は複数組み 合わせて行うことで, エネルギー削減効果が高くなる可能性がある。

「実施容易性は低いが省エネ効果は高い省エネ行動 $(\boldsymbol{\square}) 」$ とて, 「22.間隔をあけずに入浴」「38.食洗機の乾燥機能を使用しない」等 が挙げられた。また「口」に該当する「34.テレビを省エネモード」

「48.打ち水をする」「49.コンセントを抜く」等は実施容易性が「3」, 省エネ効果が「B～D」である。しかし実施しづらい側（実施容易性 が「2」以下）の省エネ行動ではなく，かつ複数行うことで削減量 
Table 10 Recommended energy-saving behaviors suitable for different household characteristics

\begin{tabular}{|c|c|c|c|c|c|c|c|c|c|c|c|c|c|c|c|c|c|c|c|}
\hline \multirow{3}{*}{\multicolumn{2}{|c|}{ 分類 }} & \multirow{3}{*}{ 番 } & \multirow{3}{*}{\multicolumn{2}{|c|}{ 省エネ行動項目 }} & \multirow{3}{*}{ 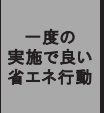 } & \multirow{3}{*}{ 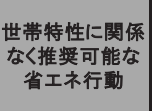 } & \multicolumn{13}{|c|}{$\begin{array}{c}\text { 推奨省エネ行動 } \\
\end{array}$} \\
\hline & & & & & & & & 家族構 & & & & 年齢 & & & 価值観 & & & イフスタイ & \\
\hline & & & & & & & $\begin{array}{c}\text { 夫婦 } \\
(N=8)\end{array}$ & $\begin{array}{l}\text { 夫诼+子 } \\
(\mathrm{N}=47)\end{array}$ & $\begin{array}{r}\text { 夫婦+ } \\
\text { 期 } \\
(\mathrm{N}=10\end{array}$ & $\begin{array}{c}\text { 未就堂児 } \\
(\mathrm{N}=3=33)\end{array}$ & $\begin{array}{c}\text { 小中学生 } \\
(\mathrm{N}=11)\end{array}$ & $\begin{array}{l}\text { 高校生以 } \\
(N=13)\end{array}$ & $\begin{array}{c}\text { 子どもいな } \\
\text { (N=8) }\end{array}$ & 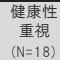 & 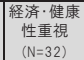 & $\begin{array}{l}\text { 経济性 } \\
\text { (N) 䘽 }\end{array}$ & $\begin{array}{l}\text { 在宅型 } \\
(\mathrm{N}=24)\end{array}$ & $\begin{array}{l}\text { 日中多出 } \\
\text { 型=14) }\end{array}$ & $\begin{array}{l}\text { 非在宅型 } \\
(\mathrm{N}=15)\end{array}$ \\
\hline & & 1 & 桘定滑度を上げる & & & $\star$ & $\Delta$ & $\Delta$ & $\Delta$ & $\Delta$ & $\Delta$ & $\Delta$ & $\Delta$ & $\Delta$ & $\Delta$ & $\Delta$ & $\Delta$ & $\Delta$ & $\Delta$ \\
\hline \multirow{6}{*}{ 空 } & 冷房 & 2 & 使用時間を短くする & & & & ? & 0 & 믈 & & & 0 & 0 & $\square$ & 0 & 0 & $\square$ & & 0 \\
\hline & & 4 & 設定温度を下げる & & & $\star \star$ & 0 & 0 & 0 & 0 & 0 & 0 & 0 & 0 & 0 & 0 & 0 & 0 & 0 \\
\hline & 暖房 & $\frac{5}{6}$ & 使用赤しない間を短くする & & & $\star \star$ & 0 & 0 & 0 & 0 & 0 & 0 & 0 & 0 & 0 & 0 & 0 & 0 & \\
\hline & フィルタ & 7 & 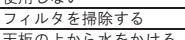 & & & $\star$ & $\Delta$ & $\Delta$ & $\Delta$ & $\Delta$ & $\Delta$ & $\Delta$ & $\Delta$ & $\Delta$ & $\Delta$ & $\Delta$ & $\Delta$ & $\Delta$ & $\Delta$ \\
\hline & 穴外機 & 8 & 天板の上から水をかける & & & & 1 & $\hat{1}$ & & & & & & & & & & & \\
\hline & 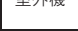 & $\frac{9}{10}$ & 日除けを設置 & & & $\star$ & $\Delta$ & $\Delta$ & $\Delta$ & $\Delta$ & $\Delta$ & $\Delta$ & $\Delta$ & $\Delta$ & $\Delta$ & $\Delta$ & $\Delta$ & $\Delta$ & $\Delta$ \\
\hline \multirow{8}{*}{ 給 } & \multirow{8}{*}{ 給湯 } & & 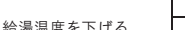 & $\begin{array}{ll}\text { 夏香 } \\
\text { 中暗 }\end{array}$ & & $t+t$ & & & & & & & & & & & & & \\
\hline & & 13 & & 冬季 & & & 0 & 마 & 0 & 마 & 0 & 0 & 0 & 0 & 맘 & 0 & 0 & 0 & 0 \\
\hline & & $\frac{14}{15}$ & 湯仙温度圭下げる & $\begin{array}{l}\text { 夏季 } \\
\text { 中間期 } \\
\end{array}$ & & 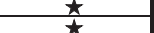 & $\Delta$ & $\Delta$ & $\Delta$ & $\Delta$ & $\Delta$ & $\Delta$ & $\Delta$ & $\Delta$ & $\Delta$ & $\Delta$ & $\Delta$ & $\Delta$ & $\Delta$ \\
\hline & & 16 & & 笗等 & & & 0 & $\square$ & 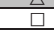 & 台 & $\square$ & $\Delta$ & 0 & $\Delta$ & 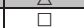 & 0 & 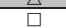 & 台 & $\Delta$ \\
\hline & & 17 & シャワーのみで済ます & 夏季 & & & $\Delta$ & $\square$ & $\square$ & $\square$ & $\square$ & $\square$ & $\Delta$ & $\square$ & $\square$ & $\Delta$ & $\square$ & $\square$ & $\square$ \\
\hline & & $\frac{18}{19}$ & & 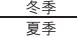 & & & & & & & & & & & & & & & \\
\hline & & 20 & 湯はりり量を減らす & $\begin{array}{ll}\text { 中間期 } \\
\text { 等 }\end{array}$ & & & 0 & $\square$ & ㅁ & $\square$ & 0 & $\square$ & 0 & ㅁ & $\square$ & 0 & 0 & $\square$ & $\square$ \\
\hline & & $\frac{21}{22}$ & 間隔を開けずに入浴する & 弪鱼 & & & 口 & $\overline{\mathbf{m}}$ & $\bar{\pi}$ & $\overline{\mathbf{E}}$ & 口 & - & E & $\bar{\theta}$ & $\overline{\mathbf{n}}$ & - & Q & 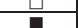 & 0 \\
\hline \multirow{14}{*}{$\begin{array}{l}\text { 家 } \\
\text { 電 } \\
\text { 誉 } \\
\text { 器 }\end{array}$} & \multirow{4}{*}{ 冷蔵庫 } & 23 & 壁とのスペースを確保 & & $\mathrm{v}$ & 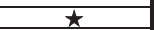 & & & & & & & & & & & & & \\
\hline & & 24 & 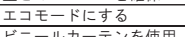 & & $v$ & $\star \star$ & (๑) & 0 & ๑) & 0 & ๑ & () & () & ○) & 0 & 0 & 0 & (๑) & 0 \\
\hline & & $\frac{25}{26}$ & 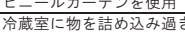 & まさな & & $\star \star$ & & & & & & & & & & & & & \\
\hline & & 27 & 熱いものは常温に冷ます & & & $\star \star$ & (๑) & ○) & (0) & $\odot$ & ๑) & ○) & ๑) & ○ & ○) & (-) & $\odot$ & ๑) & ๑) \\
\hline & & 29 & 洗罯物をまとめて洗う & & & & 0 & 0 & प & 0 & $\square$ & $\square$ & 0 & $\square$ & 0 & 0 & 0 & $\square$ & 0 \\
\hline & 洗攞機 & 30 & 高速モードで洗濯する & & & & 0 & ㅁ & 0 & $\square$ & 0 & 0 & 0 & 0 & 0 & & 0 & 0 & 0 \\
\hline & & 31 & 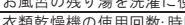 & 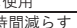 & & & $\Delta$ & ㅁ & $\Delta$ & 口 & $\Delta$ & $\Delta$ & $\Delta$ & $\Delta$ & $\Delta$ & 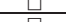 & $\Delta$ & $\Delta$ & $\square$ \\
\hline & \begin{tabular}{|l|l} 
㲦燥機 \\
\end{tabular} & $\frac{52}{33}$ & 浴窒乾燥機の使用回数·時 & 寺間成らす & & & $\vec{\square}$ & & & & प्र & 맘 & $\vec{\square}$ & 는 & & $\vec{\square}$ & & $\square$ & $\Delta$ \\
\hline & 杵レビ & 34 & 省エネモードーする & & $v$ & & प & $\square$ & $\square$ & $\square$ & $\square$ & $\square$ & $\square$ & $\square$ & $\square$ & $\square$ & $\square$ & $\square$ & $\square$ \\
\hline & 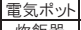 & 35 & 保温を控える & & & & ○) & 0 & $\square$ & 0 & 0 & 0 & () & $\square$ & 0 & () & 0 & 0 & 0 \\
\hline & 炊飯器 & $\frac{36}{37}$ & 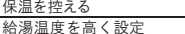 & & & $\star$ & $\frac{\Delta}{\Pi}$ & $\Delta$ & $\Delta$ & $\Delta$ & $\Delta$ & $\begin{array}{l}\Delta \\
\end{array}$ & $\begin{array}{l}\Delta \\
\end{array}$ & $\Delta$ & $\Delta$ & $\Delta$ & $\Delta$ & & $\Delta$ \\
\hline & & 38 & 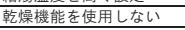 & & & & - & & 口 & & - & - & - & & 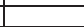 & - & & & - \\
\hline & 食洗機 & & 高速モードを傊 & & & & & & & & $\square$ & $\Pi^{-2}$ & & $\square$ & & & $\square$ & $\square$ & \\
\hline & & 年4 & 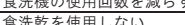 & & & & 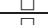 & $\square$ & & & $\square$ & $\square$ & 咞 & $\square$ & $\square$ & $\square$ & $\square$ & $\square$ & $\square$ \\
\hline \multirow{9}{*}{$\begin{array}{l}z \\
\text { 市 } \\
\text { 他 }\end{array}$} & 昭明 & 42 & & & & 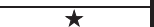 & $\triangle$ & $\Delta$ & $\Delta$ & $\Delta$ & $\Delta$ & $\Delta$ & $\triangle$ & $\Delta$ & $\Delta$ & $\Delta$ & $\Delta$ & $\Delta$ & $\Delta$ \\
\hline & 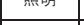 & \begin{tabular}{l|l}
43 \\
\end{tabular} & 家族が集- & & & $\star$ & $\Delta$ & $\Delta$ & $\Delta$ & & & $\Delta$ & $\Delta$ & $\Delta$ & $\Delta$ & $\Delta$ & $\Delta$ & $\Delta$ & \\
\hline & 温水洗浄 & 44 & 設定温度を下げる & & & $\star$ & $\Delta$ & $\Delta$ & $\Delta$ & $\Delta$ & $\Delta$ & $\Delta$ & $\Delta$ & $\Delta$ & $\Delta$ & $\Delta$ & $\Delta$ & $\Delta$ & $\Delta$ \\
\hline & 便座 & $\frac{45}{46}$ & 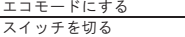 & & $\begin{array}{c}\mathrm{v} \\
\mathrm{v}\end{array}$ & $\star$ & $\Delta$ & $\frac{\Delta}{\square}$ & $\Delta$ & $\Delta$ & $\Delta$ & $\frac{\Delta}{\square}$ & $\Delta$ & $\Delta$ & $\Delta$ & $\Delta$ & $\Delta$ & $\frac{\Delta}{\square}$ & $\Delta$ \\
\hline & 通風 & 47 & 天空・空開けなどで通風る & 在図る & & $\star$ & & $\Delta$ & & & & & & & & & & & \\
\hline & 打ち水 & 48 & 打ち水をする & & & & $\square$ & & $\square$ & 口 & $\square$ & $\square$ & $\square$ & $\square$ & & $\square$ & $\square$ & $\square$ & $\square$ \\
\hline & & 49 & 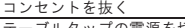 & & & & $\square$ & 口 & $\square$ & $\square$ & $\square$ & 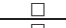 & $\square$ & $\square$ & 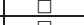 & $\square$ & $\square$ & $\square$ & ㅁ \\
\hline & 待機電力 & 51 & 主電源を切る & & & & $\square$ & प & $\vec{\square}$ & प्u & प & 맘 & प्u & 맘 & 맘 & 맘 & प्प & $\frac{\square}{\square}$ & 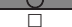 \\
\hline & & & & & & & 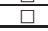 & & प्म & 品 & $\square$ & 品 & त & & & & & 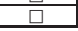 & \\
\hline
\end{tabular}

が大きくなる可能性が考えられる。すなわち「西」や「口」のつい た省エネ行動は，一般的に環境配慮や電気代削減等への意識が高い 世帯に対して推奨できる可能性があり, 実施によって削減される $\mathrm{CO}_{2}$ 排出量や電気代等の情報を提示することで居住者の意欲が向上

し，行動実施につながると推察される。

一方, 一度の実施で省エネ効果が持続する（継続的に行わなくて 良い) 省エネ行動として「34.テレビの省エネモード」「46. 温水洗浄 便座の電源を切る」「52.機器の設定変更」等が挙げられる。これら は頻繁に実施しなくて良い省エネ行動であり, Table 10で推奨しづ らいと判断されたものでも, 例外として推奨できる可能性がある。 例えば「23.冷蔵庫と壁のスペースをとる」「34.テレビの設定変更」 $\lceil 45$. 温水洗浄便座を設定変更」「46.温水洗浄便座の電源を切る」「52. 機器の設定変更」では一度の実施で省エネ効果が持続するため推奨 すべきと考えられる。

\section{7. まとめと提案}

本研究では北日本と沖縄を除く日本各地の全電化高性能戸建住宅 を対象に, 省エネ行動の実施容易性とエネルギー削減効果を調查し, 世帯の特徵に応じて推奨される省エネ行動について検討を行った。 本報で得られた主な知見を以下に記す。

i）省エネ行動実施に関して

・省エネ行動を実施した世帯は実施していない世帯と比べて省エネ 行動実施を面倒臭いと感じる割合が低くなる傾向が示された。また 電力消費量が年間約 $5.6 \%$ 少なくなり, 省エネ行動を提案することが

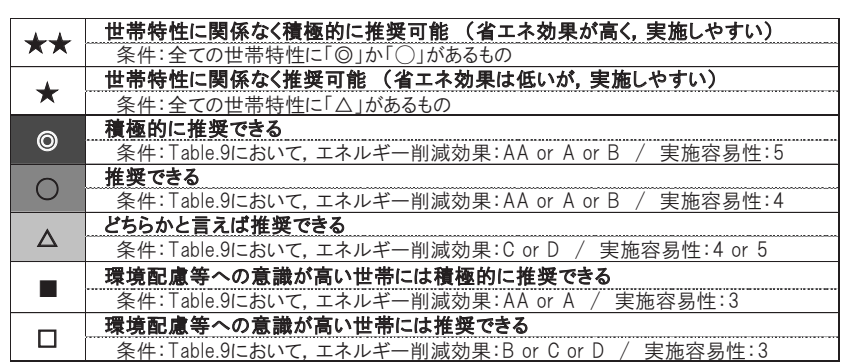

エネルギー削減に寄与する可能性が示された。

・様々な省エネ行動の継続率（日常的に実施している割合）が示さ れた。継続率は屋外で作業をするものや冬季の給湯分野, 一日に何 度も行わなければならないもので低い傾向にあった。

・家電機器等の省エネ行動は年間を通じて行うことでエネルギー削 減量が大きくなるものがあり, 継続して行うことが重要な分野であ ることが示唆された。

i i ) 推奨省エネ行動の提案に関して

・52項目の省エネ行動のエネルギー削減効果，世帯特性による実施 容易性を示し，その結果から推奨できる省エネ行動を世帯特性ごと に一覧表として示した。

・世帯を問わず推奨可能な省エネ行動には「暖房設定温度を下げる」 「暖房使用時間の短縮」「中間期に給湯温度を下げる」「冷蔵庫をエ コモード設定」「物は冷ましてから冷蔵庫に入れる」が挙げられた。 ・「冬季の湯はり温度を下げる」「中間期・冬季の湯はり量を減らす」 「洗濯物はまとめて洗濯する」「温水洗浄便座の電源を切る」「家電 
機器のスイッチ付きテーブルタップの電源を切る」等は, 親世代や 子どものいない世帯, 日常生活で経済性に価值観を置いている世帯 に推奨可能であることが示された。

・エネルギー削減効果は比較的低いが, 実施しやすい省エネ行動と して,「冷蔵庫の開閉を減らす」「冷蔵室に物を詰め過ぎない」「炊飯 器の保温を控える」「照明をこまめに消寸」等が挙げられ，世帯特性 に関係なく推奨できる可能性が示唆された。なおこれらに該当する 省エネ行動は複数組み合わせて行うことで高いエネルギー削減効果 を得られる可能性がある。

・「冷暖房を使用しない」「間隔あけずに入浴」「食洗機の乾燥機能を 使用しない」は比較的実施しづらいものの, エネルギー削減効果が 高いため, 一般的に環境配慮や電気代削減等への意識が高い世帯に は推奨できることが示唆された。

・「冷蔵庫と壁のスペースをとる」「テレビの設定変更」「温水洗浄便 座を設定変更」「温水洗浄便座の電源を切る」「機器の設定変更」は 一度の実施で省エネ効果が持続する省エネ行動であるため, 推奨す べきものであることを述べた。

なお, 今後本報で示した推奨省エネ行動に関しては, 新たな世帯 に提案し, 実施状況や提案に対する満足度, 実施後の継続率等につ いて経時的に分析する予定である。また全電化ではない一般的な世 帯に対しては, エネルギー削減効果等の結果が異なることが予想さ れるため, 新規調查対象の世帯で実績を積み上げ, 提案可能な省工 ネ行動について検討する必要があると思われる。

\section{謝辞}

本調査の一部は国土交通省の住宅·建築物省 $\mathrm{CO}_{2}$ 先導事業採択プ ロジェクト「クラウド型HEMSを活用した $\mathrm{LCCO}_{2} 60 \%$ マイナス住 宅」の一環として実施したものである。関係各社, またアンケート 調查にご協力いただいた方々に, 梁く感謝致します。

\section{参考文献}

1）経済産業省・資源エネルギー庁：平成 24 年度(2012年度)エネルギー需給実 績を取りまとめました(速報), 2013.10

2) (一財) 日本エネルギー経済研究所計量分析ユニット：平成23年度エネルギ 一環境総合戦略調査-経済産業省資源エネルギー庁委託調査-, 2012.2

3）みずほ銀行：2012年夏の生活者の節電行動, 2012.11

4）竹之下忠英，村上周三ほか 2 名：省エネ行動がもたらす住宅の $\mathrm{CO}_{2}$ 削減効 果の将来推計, 日本建築学会大会学術講演梗概集, 環境工学 I, pp.10951096, 2008.9

5）長谷川善昭, 井上隆 : 全国規模アンケートによる住宅内エネルギー消費の 実態に関する研究 世帯特性の影響と世帯間のばらつきに関する考察 その 1, 日本建築学会環境系論文集 第583号, pp.23-28, 2004.9

6）井上隆，水谷傑ほか 1 名：全国規模アンケートによる住宅内エネルギー消 費の実態に関する研究 影響を及ぼす要因に関する分析 その 2 , 日本建築 学会環境系論文集 第606号, pp.75-80,2006.8

7）森原祐介, 井上隆ほか 4 名：アンケートによる一般家庭での冷房使用実態 調査(第3報)住宅内エネルギー消費の実態と居住者の認識, 空気調和・衛生 工学会大会学術講演論文集, pp.1443-1446, 2007.9

8）石田建一，小峯裕己ほか2名：省エネ行動による家庭用消費電力量削減効 果の検証 その 1 調査概要と検針データによる省エネルギー効果, 日本建築 学会大会学術講演梗概集, 環境工学 I, pp.157-158, 2008.9

9）佐藤誠，小峯裕己ほか 2 名：省エネ行動による家庭用消費電力量削減効果 の検証 その 2 行動ごとの省エネルギー効果の推定, 日本建築学会大会学術 講演梗概集，環境工学 I , pp.159-160，2008.9

10）波多野令子，井上隆ほか4名：水まわり空間を中心とした省エネルギー性 と快適性に関する研究 第 4 報 浴室温熱環境改善による入浴エネルギー消
費削減効果の検討, 日本建築学会大会学術講演梗概集, 環境工学 I , pp.641$642,2010.9$

11）石田建一，佐藤誠：HEMSによる家庭用冷暖房・照明エネルギーの削減効

果の検証，日本建築学会環境系論文集 第595号，pp.57-64，2005.9

12）佐藤誠，石田建一：HEMSを用いたエアコンの最適制御による省エネル ギー効果 その2)エアコン省エネ量の推定, 日本建築学会大会学術講演梗概 集，環境工学 II , pp.1229-1230，2004.8

13）富越大介，伊香賀俊治ほか 2 名 : 居住者行動とエネルギー使用量の分析に 基づく省エネ行動提案ツールの構築，日本建築学会技術報告集 第19巻，第 42号, pp.655-660，2013.6

14）上野剛，中野幸夫：居住者の選好を考慮した省エネ行動選択支援ツール の開発, 電力中央研究所報告 $R$ 研究報告(07009), pp.1-20, 巻頭 $1 \sim 3$, 2008.6

15）岡本雄敏, まつ本真佑ほか 1 名 : 嗜好アンケートに基づく個人適応型省エ ネ行動推薦手法の検討, 電子情報通信学会技術研究報告, 情報ネットワー ク111(146), pp.105-110, 2011.7

16）岡本雄敏, まつ本真佑ほか 1 名 : ペルソナシナリオ法を用いた個人適応型 省エネ行動の分析法, 電子情報通信学会技術研究報告, 情報ネットワーク 110(289), pp.77-82, 2010.11

17）川上祐司，須永修通ほか 3 名：高性能戸建住宅を対象としたエネルギー消 費の特性と削減ポテンシャルに関する研究, 空気調和・衛生工学会大会学術 講演論文集，第9巻, pp.149-152, 2014.9

18）佐藤光太郎・中島裕輔ほか 1 名: 住宅における環境・エネルギー情報提供シ ステムの構築に関する研究, その7 省エネ行動とシステム使用状況の関係, 日本建築学会大会学術講演梗概集, 環境工学 II, pp.331-332, 2010.9

19) (一財)省エネルギーセンター : 家庭の省エネ大事典 2012年版, 2012.3 20）環境省：家庭でできる節電アクション,

https://funtoshare.env.go.jp/setsuden/home/，最終閲覧日2014.7.21

21) (株)三菱総合研究所 環境・エネルギー研究本部: 平成 24 年度エネルギー消 費状況調査(民生部門エネルギー消費実態調査), 2013.3

22）遠藤裕太，須永修通ほか 4 名：世帯に応じた省エネルギー行動の提案に関 する研究-アンケート調査による継続性・実行性・ストレスの考察-, 日本建築 学会大会学術講演梗概集, 環境工学 II , pp.555-556, 2013.8

23) 久和原裕輝, 須永修通ほか 4 名 : 太陽光発電住宅におけるコミュニケーシ ヨン型HEMSに関する研究 その 6 エネルギー消費に影響を及ぼす要因, 日 本建築学会大会学術講演梗概集, 環境工学 II, pp.553-554, 2013.8

24）遠藤裕太, 須永修通ほか 3 名 : 世帯特性に応じた省エネ行動の提案に関す る研究-行動実施に影響する因子-，太陽/風力エネルギー講演論文集， pp.599-602, 2013.11

25）烟泰彦, 須永修通ほか 4 名：住宅における省エネルギー行動に関する研究 1 . 研究の概要と対象邸・居住者の属性, 日本建築学会大会学術講演梗概 集, 環境工学 II , pp.587-588, 2014.9

26）川上祐司，須永修通ほか 4 名：住宅における省エネルギー行動に関する研 究 2. エネルギー消費の特性と削減ポテンシャルの検討, 日本建築学会大 会学術講演梗概集，環境工学 II, pp.589-590, 2014.9

27）中野郁也, 須永修通ほか5名：住宅における省エネルギー行動に関する研 究 3 . 暖房に関する省エネ行動の意識と効果, 日本建築学会大会学術講演 梗概集，環境工学 II ，pp.591-592，2014.9

28）小野寺宏子, 須永修通ほか 4 名：住宅における省エネルギー行動に関する 研究 4 . 給湯に関する省エネ行動の意識と効果, 日本建築学会大会学術講 演梗概集，環境工学 II , pp.593-594, 2014.9

29）遠藤裕太, 須永修通ほか 4 名 : 住宅における省エネルギー行動に関する研 究 5 . 省エネ行動の実施に伴う電力消費と省エネ意識の変化, 日本建築学 会大会学術講演梗概集，環境工学 II , pp.595-596, 2014.9

30）須永修通，遠藤裕太ほか 4 名：高性能住宅におけるHEMS と省エネ行動の 効果, BECC JAPAN 2014(東京)，2014.9

31）遠藤裕太，須永修通ほか 3 名：高性能住宅における省エネ行動の実施容易 性とエネルギー削減効果に関する研究，平成 26 年度日本太陽エネルギー学 会合同研究発表会(いわき)投稿済み, 2014.11

\section{注}

注1）対象世帯は住宅メーカーが自社のホームページ上で募集し，その協力世 帯を関東甲信, 北陸, 東海, 近畿, 中四国, 九州の6地域に分類して解析し た。なお甲信や北陸地域における気候特性が住宅内エネルギー消費量に与

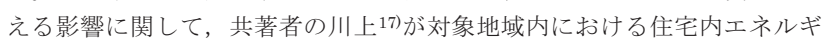
一消費量に差がないことを示している。 
注2）アンケート調査において, 対象世帯に省エネの実施を要請した省エネ行 動の項目数は全部で55項目である。しかし分析内容や有効データの数等を 考慮し，本報ではTable 6に記す52項目の省エネ行動を対象としている。

注3）省エネ行動実施調査では, 電化製品の備え付けられていない世帯に対す る対応として, アンケート回答用紙に「対象機器を持っていない／持って いるが，使用していない」という項目を設けた。また機器を保有していな い世帯は分析対象から除外している。

注4）「省エネ行動実施に関する調査」では, Table 4に示す省エネ行動の各 項目を季節に応じて居住者に提示し，居住者に実施できる省エネ行動を行 ってもらう。例えば暖房の場合, 暖房に関寸る省エネ行動として,「暖房 の設定温度下げる」「暖房の使用時間を控える」「暖房を使用しない」の3 つの行動を提示し, 居住者はその3つの中からできると思った行動を選択し て実施する(複数実施可)。

注5) エアコンフィルタ (No.7)は7〜8月中に一度の実施を要請し, 洗濯機や乾 燥機, 食洗機(No.29〜33,37〜 41) は連続した7日間の実施を要請した。また 上記に加え, 打ち水・通風に関寸る省エネ行動に対して, 実施した時間带 も回答してもらう形式とした。

注6）本研究では住宅単位で省エネ行動の効果の分析を行っており, 対象世帯 が二世帯住宅でも回答があった場合は分析対象としている。

注7）二世帯住宅14世帯のうち(Fig.1参照), 消費電力量を各世帯で個別に測定 している世帯は 5 世帯あり, 子世帯の消費電力量のみ測定している。

注8）重回帰分析では目的変数に各住宅の日積算消費電力量, 説明変数に日平 均外気温, 日最高・最低気温, 日照時間, 冷房度日(D22-22), 暖房度日 (D18-18)の6変数を用いた。期間は2012.10.1〜2014.3.31である。

注9) 継続率は事後調査(Table 3に示寸省エネ行動の実施度合いを「以前から 実施している」「アンケートで実施するようになった」「実施できない」 の3項目で回答してもらう)の回答結果より求めた。

注10）子どものいない世帯は「実施邸」全体の約 $13 \%(10$ 世帯)であり, 平均 世帯主年齢は49.8歳である。子どものいない世帯のうち，60歳以下の世帯 が60\%(6世帯)，60歳以上の世帯が40\%(4世帯)である。

注11）分類はクラスター分析の階層型凝縮法, ウォード法を用いた。価值観 の分類はアンケート調査で「日常生活で重視する項目 (1～5位)は快適性, 経済性, 環境性, 社会性, 健康安全性のどれですか? の回答データを参 考にした。Fig.Aに上記の回答によるクラスター分析結果を示す。樹形図よ り3グループに分類し, Fig.Bの結果から各グループを「健康性重視」「経 済性重視」「経済・健康性重視」とした。Fig.Bの優先得点は優先順位1位を 5 点, 2 位を 4 点， $\cdots, 5$ 位を 1 点としている。

注12）ライフスタイルは住宅での在宅時間を基に分類した。Fig.Cに在宅時間 によるクラスター分析結果を示す。樹形図より 3 グループに分類し, Fig.D の結果から各グループを「在宅型」「日中外出型」「非在宅型」とした。

注13）有意差の算出は各省エネ行動の実施世帯数からカイ二乗検定を用いた。 注14）省エネ行動を実施した日(最大 3 日間,一部7日間)の日平均電力量と省エ ネ行動実施前1週間の日平均電力量の差を取ることでエネルギー削減量を 算出した(No.1〜33, No.37〜 52)。また解析に用いた測定回路は用途別8回 路の中から行動する際に消費量の変動に関係のある回路を選出した。

注15）No.34〜36は用途別8回路の電力データでは削減量を算出できないため, 対象世帯の居住者自身に省エネ行動実施前後の電力消費を電力モニターで 確認, アンケートに記入してもらい, その回答の差の平均より算出した (No.34 36)。

注16）削減量は基本的に単位日, 単位面積, 単位人, 単位世帯当たり ([Wh/ 日 $\cdot \mathrm{m}^{2} \cdot$ 人・世帯] $)$ として算出している。しかし空調や給湯, 乾燥機の分野の省 エネ行動(No.1〜22,37)では, 日常の使用時間や省エネ行動実施の際に変更 した設定温度, 使用を控えた時間数を考慮して, それらも単位温度, 単位 時間当たりで付加した值として算出している。

注17）実施容易性は「省エネ行動の実施のしやすさ」として定義した。

注18）第4章のストレス・継続性評価, 継続率のアンケート有効回答数(母数) により重み付けした加重平均を行い，0〜1の值の範囲で算出した。ただし ストレス・継続性評価は評価点の最大である3で除し，0１の值に補正して 計算に用いた。次式は実施容易性の算出に用いた加重平均の式である。

$$
\left(x N_{x}+y N_{y}+z N_{z}\right) /\left(N_{x}+N_{y}+N_{z}\right)
$$

$x$ : ストレス評価(補正後),$y$ : 継続性評価(補正後),$z$ : 継続率, $N_{x}$ : ストレス評 価の有効回答数, $N_{y}$ : 継続性の有効回答数, $N_{Z}$ : 継続率の有効回答数

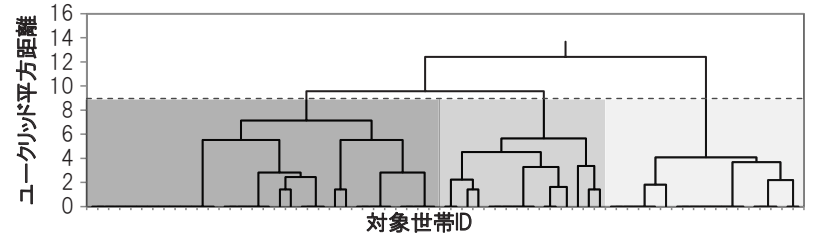

Fig.A Results of cluster analysis by question of note 3

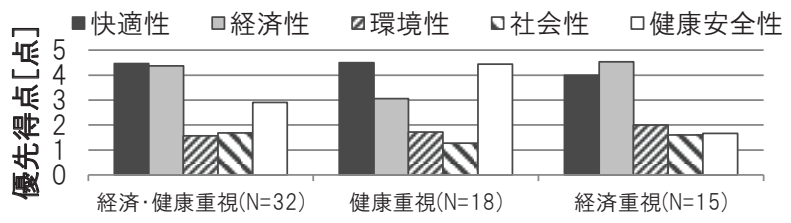

Fig.B Points of each group classified by result of Fig.A

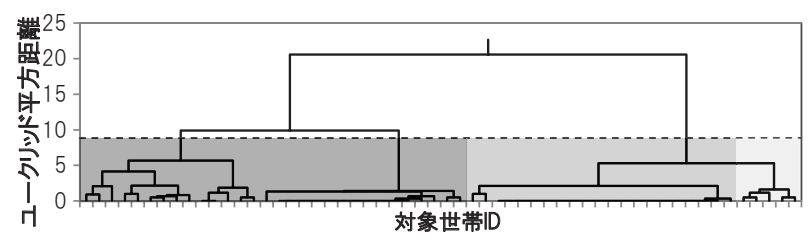

Fig.C Results of cluster analysis by staying home time

-09:00 12:00 12:00 15:00 • 15:00 18:00 \$18:00 21:00

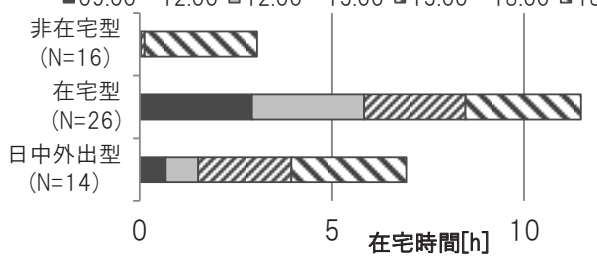

15

Fig.D Staying home time of group classified by result of Fig.C 


\section{STUDY ON SUGGESTIONS OF ENERGY-SAVING BEHAVIORS SUITABLE FOR DIFFERENT HOUSEHOLD CHARACTERISTICS IN ALL-ELECTRIC DETACHED HOUSING}

Recommended behavior in terms of ease of implementation and energy reduction effect

$$
\begin{gathered}
\text { Yuta ENDOH* , Nobuyuki SUNAGA **, Hiroko ONODERA ***, } \\
\text { Yuji KAWAKAMI* and Yasuhiko HATA**** } \\
\text { * Grad. Stud., Dept. of Arch. and Bld. Eng., Tokyo Metropolitan Univ. } \\
\text { ** Prof., Tokyo Metropolitan Univ., Dr.Eng. } \\
{ }^{* * *} \text { Assistant, Dept. of Arch. and Bld. Eng., Tokyo Metropolitan Univ. } \\
\text { **** Sekisui Chemical Co., Ltd. }
\end{gathered}
$$

This study proposes appropriate energy-saving behaviors for different household characteristics. In the study, a questionnaire survey to investigate psychological evaluation of the energy-saving behaviors was conducted for single-family houses in various locations throughout Japan except Northern Japan and Okinawa, their electric energy consumption was measured, and the ease and effect of the energy-saving behaviors were analyzed. Then recommended energy-saving behaviors for each household characteristic were examined.

In this paper, the difference in the psychological evaluation by the residents and in the energy consumption between those who took energy-saving behaviors (ESB) and those who did not (NESB) is presented. Also, the energy-saving-behavior-caused stress and the persistence rate and energy-saved amount of the households who actually took the energy-saving behaviors are given. The paper also shows the result of the study that was developed from these results on the recommended energy-saving behaviors for each of the household characteristics. The major results of the present study are as follows.

1) Compared to the NESB, ESB tended to feel that it was less bothersome to adopt the behaviors.

2) It is estimated the electric energy consumption of ESB is less about 5.6\% per year than that of NESB, which indicated that the proposal of the energy-saving behaviors could actually contribute to energy reduction.

3) The energy reduction effects of the fifty two energy-saving behaviors and the ease of taking the energy-saving behaviors for different household characteristics were presented. The recommended energy-saving behaviors for each of the household characteristics obtained from the result were listed.

4) The recommended energy-saving behaviors for all the households included "lowering of preset temperature of heaters," "shortening of use hours of heaters," "lowering of hot water supply temperature in the interim period," "using energy-saving mode of refrigerators," and "putting things in refrigerators after cooling them."

5) "Lowering of bath water temperature in winter," "reducing the bath water volume in the interim period and winter," "washing the laundry as a whole," "switching off toilet seat heater," and "turning off the switch of power strips of electric appliances" could be recommended to families with no grandparent or child or to those who focused on economic efficiency in their daily lives.

The effectiveness of the energy-saving behaviors recommended in this paper still requires examination. Therefore, we will propose the recommended energy-saving behaviors to new families and analyze, over the course of time, their energy-saving performance, how satisfied they are with the proposition, and their persistent rate of taking the behaviors. It will also be necessary to examine the energy-saving behaviors that can be proposed to general families who live in non-all-electric houses. 